\title{
A CALL FOR THE RECOGNITION AND EMPOWERMENT OF WOMEN IN MINISTRY IN THE METHODIST CHURCH OF SOUTHERN AFRICA
}

\author{
Phemelo O. Marumo \\ Department of Theology and Philosophy, North-West University - Mafikeng \\ campus \\ phemelo.marumo@nwu.ac.za
}

\section{ABSTRACT}

Women were already in ministry in Old and New Testament times, though they were not officially recognised as ministers as they are today. This practice was adopted by the Methodist Church of Southern Africa (MCSA). Despite the profound move of the MCSA to enable women to enter the ministry and serve as ministers in the MCSA, female clergy are still being ostracised. This was affirmed by the Bishop of the Cape of Good Hope District, Reverend Michel Hansrod, in an address to the synod. He conceded the following: "It is with great sadness that we recognise and confess our slowness in affording women the opportunities of leadership and poor stationing." This statement implies that clergywomen in the MCSA are still regarded as unsuited to be leaders. This article sets out to offer the MCSA insight into the best way to resolve the problem of ostracism and disempowerment of clergywomen in ministry in the MCSA. The article highlights the historical background of women in ministry and from that perspective, brings forth God's intention in creating humanity. Then it offers a discourse on how the MCSA neglects women in ministry, in contradiction to Scripture. Finally, the article formulates a missional paradigm embedded in the missio Dei that could assist the MCSA in addressing the pleas of women in ministry.

Keywords: Female clergy; ministry; MCSA; ordination; missio Dei

\section{UNISA $\cong$}




\section{HISTORICAL BACKGROUND}

Since the inception of the MCSA in South Africa, by Reverend Barnabas Shaw on 14 April 1816, the MCSA has been the man's domain. ${ }^{1}$ Men occupied all positions in the church, which made women out to be inferior. Another aspect in this relation was the supervisory nature between men and women in the MCSA; women had to report to men. Even in the church mission organisation men remained prominent in their roles as leaders during workshops to and teachers of women.

Despite the above, the first woman to be ordained as a deacon and later a minister of the Word and Sacrament was Constance Oosthuizen in 1976, appointed upon the departure of the then deaconess for Canada (Mkhwanazi 2014, 32; Oosthuizen 1990, 45). According to Mkhwanazi $(2014,32)$, Dorothy Spink then followed as candidate, as a probationer deaconess, and was subsequently ordained in 1978. He further adds that the Deacon Order contributed immensely to the ordination of the first black clergywoman, Nikiwe Mavis Mbilini, who was ordained in 1985 (Mkhwanazi 2014, 32). It took the MCSA 160 years, from the year of its inception to 1976, to recognise and accept that women can play an important role in the ministry of the Word and Sacrament. Women have now been in ministry in the MCSA since 1976. Despite women's admittance to the ministry, the past 40 years of the MCSA have been characterised by marginalisation, oppression and degradation of women in ministry. ${ }^{2}$

The Cape of Good Hope District 2016 Synod notably recognised the sterling contribution of women in ministry, especially the actions and continued action within the church by clergywomen. The synod ${ }^{3}$ further acknowledged Constance Oosthuizen, who served for years as deacon and was the first woman to be ordained, after the deliberations of the 1975 conference held in Kimberley and the subsequent one held in Benoni brought about the realisation of the injustice done to women and its inconsistency with Scripture.

Despite the realisation of the Good Hope Synod, women in ministry continue to suffer marginalisation and segregation in the MCSA. This can be ascribed to the tendency of African men, predominant in the MCSA, toward patriarchalism. ${ }^{4}$ One of the elements of patriarchalism is the belief that women are inferior to men. This mind-set has ultimately influenced African men's view of women. The practice has even invaded the church, in which culturalism plays an important role. The treatment

1 Methodist Church of Southern Africa (MCSA). History. www.methodist.org.za/heritage/southafrican-history (accessed 29 October 2016).

2 Dimension 2015, 16 (16): 1.

3 An assembly of the clergy and sometimes also the laity in a diocese or other division of a particular Church. www.oxforddictionaries.com/definition/english/synod

4 Patriarchalism is a political theory that arose in England in the seventeenth century that defended the concept of absolute power for the monarchy, through language that emphasised the "paternal" power of the king over the state and his subjects. https://en.wikipedia.org/wiki/Patriarchalism (accessed 30 November 2016). 
that women are subjected to in the church, speaks loud and clear of patriarchalism (Ruether 1993, 75).

The impact of patriarchalism is confirmed by Chitando $(2012,73)$, who argues that "women in Africa as is the case the world over generally entered the academia world later than their male counterparts". This can be attributed to various factors, among which the obligation imposed on women to fulfil household duties and obey their husbands. It is a mentality and ideology common to different nations. This practice contributed enormously to women being regarded as subjects who account to men.

In support of the above, Siyandawrites.com (2012) asserts that patriarchy has been defined as a gendered power system. It is a network of social, political and economic relationships through which men dominate and control female labour, reproduction and sexuality as well as define women's status, privileges and rights in a society. It is a successful system, because those that gain this privilege are often unaware of it and, therefore, inadvertently perpetuate the ill treatment of the people in this society whose suffering is the fulcrum upon which this society turns. It is also believed that this social system has managed to survive for so long because its chief psychological weapon is its universality as well as its longevity. ${ }^{5}$

\section{INTRODUCTION}

Mercy Oduyoye $(2001,94)$ argues that women have been carrying the knowledge that men were oppressing them for years, but conditions never allowed them to raise their voices. She states that "over time, African women had to learn to know their oppressors, but had held their peace, because when your hand is in someone's mouth, you do not hit that person on the head" (Oduyoye 2001, 94). This could describe the MCSA's treatment of women in ministry, i.e. since women in ministry are under the headship of men, they do not object to the marginalisation they have to endure. Man, as the head, is extending women the favour of being ministers. This has been a feature of African culture, even practised by the church. African culture is patriarchal in origin and colours the practices in all African institutions. It is the woman's duty to rear children and manage the household. This patriarchal approach to gender has filtered through to the religious sector of the community, i.e. the church.

Presently, according to Mkhwanazi and Kgatla $(2015,182)$, the majority of female ministers in the MCSA are stationed in rural areas under the supervision of male ministers and they usually enjoy little empathy, due to their cultural background. It is a feature evident in all aspects of African culture (e.g. marriage, tribal custom etc.), whereby women are deemed second-class citizens and thus deserve to be treated as such. African culture and beliefs direct the African worldview and give

$5 \mathrm{https}: / /$ siyandawrites.com/.../patriarchy-is-the-parasite-that-african-culture-must-rid-itself (accessed 1 November 2016). 
perspective to African thinking. The cultural mind-set dictates and controls the way the African makes sense of life. This is also applicable to the church and the reason that the observance of culture often dominates the faith and practice of Christianity.

The inception of Methodism was not accompanied by other views, such as taking cognisance of worldview, culture, contextualisation and patriarchy. The congregation ministered to was not familiarised with the concept of female ministry and these women were not properly trained in matters that affect their calling and the community in which they would be working. Women in ministry were allowed into ministry with the baggage of tribalism that considered women subordinate to men and to be treated as such. It is a notion that has never been eradicated. A further aspect that was not eliminated was lobola ${ }^{6}$ which demeans women. It turns women into objects that can be bought and can be viewed as well as treated as such, according to Mkhwanazi and Kgatla $(2015,182)$, which is why women in ministry are often not accorded due respect by the congregation. In reporting to conference in 2015, Reverend Charmaine Morgan remarked as follows:

Starting now we celebrate the Year of celebrating Women Clergy. 40 years after the Ordination of the first woman as a minister, $17 \%$ of our clergy are women, $40 \%$ of our Superintendents are women, and no women Bishops...but we still have a far way to go before we can say we have achieved our goals. ${ }^{7}$

Mkhwanazi's findings $(2014,33)$ reflect that in many African circuits members expect that female ministers must preside over all church services such as funerals, sacraments and the like with a covered head. Mkhwanazi further adds that in other cases, the same male minister's counterparts do not allow female ministers to conduct the service during their menstruation, because according to culture they are unclean (Mkhwanazi 2014, 33).

The above can be attributed to how culture and worldview have directed women's treatment in Africa. According to Chifungo (2015, 153-154), in "Living in Dignity", there are cultural teachings that contribute towards the absence of women in the theological positions of ministry, deaconship and other church leadership roles. Chifungo $(2015,153-154)$ argues that this can be ascribed to the following notions about women:

- Women are a source of evil: This relates to the Fall narrative in Genesis. It is the perception that "women are the cause of sin", the orchestrators of sin and are, therefore, evil in character and should be treated as such. Evil and Christianity are parallel, the devilishness of women makes them unsuitable to hold any office that is religious in nature.

6 An African custom in which a bridegroom's family makes a payment in cattle or cash to the bride's family shortly before the marriage (from Nguni ukulobola to give the brideprice) www. thefreedictionary.com/lobola

7 MCSA Minutes of Conference 2015. 
- Women are unreliable: Since women allowed themselves to be deceived by the snake in Eden, they cannot be trusted with anything. So including them in pastoral matters will not be of benefit to the church and is likely to destroy the church, since women are unable to keep a secret and maintain silence.

- Women are volatile: A church position of leadership requires patience, empathy and virtue, which women lack. They erupt at the drop of a hat and placing them in a position of trust and leadership will compromise the church and God's mission.

- Women are child bearers and homemakers: Marriage means to be responsible to your husband and family. It is the woman's primary duty and responsibility to ensure that the family remains intact and that the children are fed and learn to fulfil their chores. Women are also obliged to satisfy the desires of their husbands at all times. Given these "mammoth" tasks, women would not be in a position to both fulfil their family responsibilities as well as that of the community they would be serving.

It is obvious from the above that women have been deprived of expressing and developing their potential as human beings, made in the image of God. Furthermore, this practice linked to culture has led to the dilution of Christianity. It is a practice alive and well in the MCSA and has led to the marginalisation of women in ministry in the MCSA. Despite the present marginalisation of women evident in the MCSA, due to culturalism, there has been some progress in the MCSA, but at a snail's pace when it comes to female clergy. The MCSA should endeavour to seek means and ways of ensuring that female clergy assume leadership positions and thus abide by God's intentions of creation.

It would seem that the MCSA has embraced the marginalisation of women, given its "silence" on women in ministry. As a "silent" contributor to and participant in segregating women in the church, the MCSA has been non-committal - yet its action says a great deal about the treatment of women (especially in ministry). This leads to the conclusion that the MCSA transgresses Scripture teachings about women and their role in the Old and New Testaments as well in the community, especially in the church. The question is whether the MCSA prefers listening to culture over God? Answering this question places us in a position to say if the call for recognition and empowerment of women in the ministry of the MCSA is in line with Scripture or not. The article thus investigates Scripture's teachings about humanity and the call to serve God.

\section{SCRIPTURE AND HUMANITY}

According to Marumo (2016:30), the foundation of the Biblical Christian paradigm on creation is that (both man and woman) are created in the image of God (imago 
Dei) ${ }^{8}$ which is clear from the description of humanity's creation in Genesis 1:26: "Now we will make humans, and they will be like us. We will let them rule the fish, the birds, and all other living creatures." This verse relates the purpose of creation. Man is created in the image of God in order to have dominion, but not ownership, denoted with the word "rule". In this sense, humanity can indeed be called God's representative on earth (Hoekema 1994, 37; Loader 1987, 18).

This representative is seen as the steward or caretaker of the earth, demonstrating the biblical paradigm of Genesis 2 that humans are caretakers of God's creation. This understanding is illustrated in the reference of Strivers $(2004,81)$ "that all creatures are good". Strivers $(2004,81)$ explains as follows:

Mankind is created in the image of God with a special dignity bestowed upon them. This special dignity conveys not moral superiority, but a call to responsibility and servanthood to the rest of creation. This dignity furthermore has its own intrinsic value as part of God's created order. Mankind has dominion, but as God's representative this dominion is not absolute - i.e. mankind is not the absolute ruler, but a caretaker.

The mandate is to keep and cultivate the earth as conscientious steward, enjoying God and creation forever. Strivers $(2004,81)$ concludes that in today's context:

...it means to restore, protect and preserve both human and natural communities. It means connection to the earth, appreciation of God's spirit in nature - including humanity as his creation - and awe at the wonder of it all. It also means redemption; redemption from sin in order to respond with love and justice to the neighbour and to be a good steward for other species, free from exploitation.

It is thus clear from the above that the biblical Christian paradigm of humanity is based on the creation narrative, as set out in Genesis 2:18. It implies that mankind's stewardship on earth is not confined to economics, but encompasses the whole of life of all inhabitants of the earth. Stewardship is from God and mandated by him to humanity as the Creator of heaven and earth (Genesis 1). He does not relinquish His ownership. Full ownership of the earth belongs to God; humanity is merely a steward who must act according to God's mandate and plan.

The above clearly proves that God granted humankind dignity, blessings and the task of stewardship role from the beginning, with no mention of any distinction between gender and race. Humanity included both man and woman, implying equal positions and equal status for both. The equality of man and women in the eyes of God brought glory to God and gave him a sense of pride; hence in His concluding remarks God said "be fruitful and multiply, fill the earth and subdue it" (Genesis

8 "It is essentially a reflection in personhood of God, which is itself the lively or quickening image of God. Man has thus been made such that it is humanity's 'special duty' to give ear to the Word of God. Imago Dei is God's pure grace and man's response to that act of grace" (Hoekema 1994, 47). 
1:28). This blessing leads to the conclusion that God consciously looked upon man and woman as equal.

In the preceding verse (Genesis 1:27) the equality is reaffirmed and ratified by Scripture: "So God created man in His own image; in the image of God He created him; male and female. He created them." This clearly shows God instituting the equality of all humanity and the task of stewardship.

In stewardship there is a prime and directive element in its pastoral function. It brings forth that all creatures on earth are to be looked after and nurtured for the sake of the glory of God. This is applicable to all facets of life, including ministry. Ministry is imperative as a result of the Fall of humanity. Horell $(2009,138)$ explains as follows:

God manifests a multiplicity of affections - all as a moral, purposeful Being. Just as Scripture establishes that each member of the Godhead reasons, exercises volition and manifests a plurality of feelings, so finite persons evince similar characteristics. Other aspects of the divine image include creativity, aesthetic appreciation, moral conscience, aptitude for dominion, a sense of immortality as well as the desire and capacity for an I-thou relationship.

Human beings may have fallen into sin and suffer the effects of the Fall and the imago Dei may be disfigured, but it is not beyond recognition. Human beings have eternal value, because the Creator of the universe is also personal and God has come to humanity in Jesus Christ, the express image and manifestation of God. Horell $(2009,139)$ adds that:

...this manifestation of God gives Christians a new life, which is prepared for them by God Himself. Because God owns and loves his creation, God is grateful for that. That is why in Christianity the doctrine of God as Father, Son and Holy Spirit is the structure and ontological ground for the realities of personhood; self-consciousness, rationality, self-determinative choices, a plethora of affections and emotions, a sense of afterlife, moral sensibilities of right and wrong, and the capacity for relationships with God and with other human beings. In Trinitarian faith, humanity has found its home.

In line with the above, it is asserted that the Trinitarian faith is not selective and is intended for both man and woman. It is manifested in both, as people were made in the image of God. It did introduce segregation of gender. Sin only affected the image, the origin remained intact. This can be related to both man and woman being given the same status in matters of faith, religion and stewardship - and both were punished by God for sinning. The pastoral blessing still guides both of them, evident in their roles in the Old and New Testaments as well as in the post-modern era.

The MCSA has partly failed to carry out the mandate outlined in Genesis 1-2. The failure of the church relates to the issues of patriarchy, culture and worldview. It is also important, however, for the MCSA to revisit the creation narrative and verify where it has gone off track. It refers to the assertions made above and also that of 
Reverend Charmaine Morgan (in MCSA Minutes of Conference report 2015), in terms of the disparity between male and female clergy in the MCSA.

\section{ROLE OF WOMEN IN THE OLD TESTAMENT}

The Old Testament tells of man and women sharing in the sacred meals and great annual feasts (Deuteronomy 16:11-14). These women included the likes of Miriam, who was a singer, poetess and prophetess (Exodus 15:20). Deborah was a ruler, prophetess, judge and poetess. God used these women to participate in the missio Dei. ${ }^{9}$

Like most women whom God calls to leadership, Deborah apparently faced at least one man who struggled to receive God's Word through a female vessel. His name was Barak and because he was sceptical about Deborah's prophetic instructions for him to go to war against the Canaanite general Sisera, she informed him that the honour of killing Sisera would go to a woman. She was right; Jael is recorded in Scripture as the lady who drove a tent peg through a sleeping Sisera's head (cf. Judges 4). The story ends with Barak singing a duet with Deborah! The lyrics are full of praise for both Deborah and Jael (Judges 5), so perhaps Barak became a believer in women's ministry after all.

The other woman of note in the Old Testament is Athaliah. She was instrumental in easing the tension between Israel and Judah to maintain political stability, instead of opposing Yahwism. This reflects her political astuteness as the only woman in the Old Testament who demonstrated the ability to lead the nation (Mtshiselwa 2015, 7-8). Mtshiselwa (2015) is supported in this by Mtshiselwa and Masenya (ngwan'a Mphahlele) $(2016,7)$, who assert that although Athaliah was portrayed in a negative light due to her part in the elimination of all royal heirs (2 Kings 11:1), the role she played in ancient Israel is equally worthy of attention and affirmation. Her experiences of patriarchal bias against women, in a male-dominated arena, did not deter her from ruling as queen in ancient Israel.

The above clearly shows the patriarchal tendencies and culture that contributed towards women's exclusion from leadership positions by the church and State. It, furthermore, reflects that if given the opportunity, women could contribute positively to evangelism, church growth, development, leadership positions and the spirituality of the church. Therefore, we need women in ministry.

A third woman mentioned in the Old Testament, as being a well-respected prophetess, is Huldah. God used her to give reliable prophetic insight and instruction to a man, the troubled King Josiah of Judah (2 Kings 22). Again we see an example of God using a woman to instruct a man. Most likely, Huldah served God in this kind

9 Mission of God - a Trinitarian theology of mission that pivots around God the Father as the initiator, the Son as the implementer, the Holy Spirit as the empowerer and the church as the participant and agent (Bosch 2007, 390). 
of a ministry with some degree of regularity, otherwise Josiah would not have had such faith in her words to him.

But why did God call Miriam, Deborah and Huldah to be prophetesses? Couldn't He have called men instead?

Certainly God could have called men to do exactly what those three women did, but He didn't and this has never been explained. The lesson to be learned here is that we had better be careful about putting God in a box when it comes to whom He calls to ministry. Admittedly, God normally singled out men for leadership tasks in the Old Testament - and people had to leave it to God to call whomever He deemed fit.

\section{ROLE OF WOMEN IN THE NEW TESTAMENT}

The church formation started in the Old Testament and was fulfilled in the New Testament. The New Testament inherited the language, belief, liturgy and Scripture of the Old Testament (Ericson 1987, 338). Jesus Christ, as High Priest, came to restore the social and religious life of patriarchal culture to equality and called them all children of God (John 1:12). No longer was it Jew, Greek, slave, male, female but simply children of God; one big family made in the image of God, to serve God alone (Galatians 3:27-28).

This refers to the resurrection narrative of Mary Magdalene, who was regarded a prostitute. Her witnessing of the resurrection made her an appointed apostle of the church of Christ (Rutoro 2012:163). In the New Testament, Paul is very clear when it comes to women's participation in church activities. Paul prohibited women from speaking and teaching in the church, as described in 1 Timothy 2:11-14, because they were not properly trained and not because they were inferior or supposed to defer to men. They had not received the requisite training, as a result of cultural prohibitions against their participation in church leadership and issues (Miller 2013).

When Jesus was resurrected, an angel called on at least three women to teach Jesus' male disciples. Those women were instructed to tell the disciples that Jesus had risen and that He would appear to them in Galilee. But that is not all. A short time later, Jesus Himself appeared to the same women and commanded them to instruct the disciples to go to Galilee (Matthew 28:1-10; Mark 16:1-7).

Thus we realise that the exclusion of women in ministry was not the intent of either Jesus or God. In so many other ways, God seeks to use women for His glory and $\mathrm{He}$ has been doing so for thousands of years. Scripture speaks of many positive contributions that women have made to God's Kingdom, some of which we have already considered. Let us not forget that some of Jesus' closest friends were women (John 11:5) and that women supported His ministry financially (Luke 8:1-3); something that is not said of any of the men.

The woman at the well of Samaria testified of Christ to the men of her village and many came to believe in him (John 4:28-30,39). A female disciple, named 
Tabitha, is said to have been abounding with deeds of kindness and charity (Acts 9:36). It was a woman who anointed Jesus for burial and for which He commended her in the face of protests from a number of men (Mark 14:3-9). Finally, the Bible records that women wept for Jesus as He carried His cross through the streets of Jerusalem, something not said of a single man. These examples and many more should encourage women to rise up and fulfil their God-ordained ministries. We need them all!

There are several other women mentioned in the New Testament who contributed towards ministry. These women played a prominent part in taking the ministry forward in the formation of the church - the likes of Lydia, Joanna and Susanna, to mention but a few.

Wijngaards (2011:1) affirms the above by stating that women are also called by God to the vocation of priesthood; this internal invitation is not confined to men. All people are called to priesthood in all nations. The gender is not specified.

From the above it is maintained that it is significant that Jesus chose to appear first to women and then to men. Secondly, if there was something fundamentally or morally wrong with women teaching men, one would think that Jesus wouldn't have instructed women to teach men about His resurrection - hardly a trivial piece of information and one that He could have delivered on His own (and in fact later did). No one can argue the fact that the Lord Jesus instructed women to teach a vital truth and give spiritual instruction to certain men.

\section{NEGLECT OF WOMEN IN MINISTRY IN THE MCSA}

As mentioned before in her report to the 2015 conference of the MCSA, the General Secretary, Reverend Charmaine Morgan (Minutes of the MCSA Conference 2015) remarked: "40 years after the Ordination of the first woman as minister, $17 \%$ of our clergy are women, $4 \%$ of our Superintendents are women and no women are Bishops."

The above statement clearly indicates that female clergy in the MCSA are ostracised and marginalised. The numbers say a great deal about patriarchy and marginalisation of clergywomen in the MCSA. The reported four per cent representing women in positions of leadership is alarming. The question that comes to mind is whether the MCSA, as church based on the teachings of Jesus Christ, is following what Jesus initiated or whether the MCSA, as church, is fostering the disregard of the potential and leadership attributes of women within its domain?

It must be noted that ministry in the world has been characterised by women in action. It has seen women participating in ministry from low positions in the church to ones of leadership, through God-given initiatives and potential. Due to the marginalisation of women, their heroic deeds have gone either unrecorded or if recorded, those deeds were not given their just due - especially in ministry. 
One of the many examples in South Arica is that of Charlotte Maxeke, who was a leader in the African Methodist Episcopal Church, the first African woman from South Africa to obtain a BSc and the first African woman to be made a probation officer. She may also be called the "Mother of Ethiopia", given the part she played in the amalgamation of the Ethiopian church and the African Methodist Episcopal Church (AMEC). Maxeke is said to have been greatly influenced by AMEC and through her connections with the Ethiopian church, the AMEC was established in South Africa. She became the organiser of the Women's Mite Missionary Society in Johannesburg and then moved to the Polokwane area. Here she joined her family in Dwaars River, under Chief Ramakgopa, who gave her the money to start a school. The school could not be continued, however, due to lack of government funding and the poverty of the local community (Millard 1999).

Another woman of note is Ms Susan Ngwanakhetha Mophoso, a full member of the MCSA. During her tenure she was the District Secretary of the Christian Citizenship Department, which was involved in community work. She was a member of the Central Committee that developed and launched the MCSA Sepedi Hymn Book in 1982. She worked under the stalwarts of the MCSA; former Bishop of the MCSA, Dr Stanley Mogoba; Revs D.M. Manamela, R.A.M. Thema, Z.S.M. Mosai, H.R. Phaswane and Prof. Mafori Mphahlele. It was during this time that she showed the qualities of leadership that contributed enormously to the success of the project. (This history is undocumented, but orally confirmed by Dr B. Koma.)

In paying tribute to the late Reverend Constance Oosthuizen, Bishop Mike Voster of the MCSA (Natal Coast District) highlighted the plight facing female clergy in the MCSA. He recalled how the late reverend had to go a long way to be ordained as minister of the Word and Sacrament in the MCSA. The church that declared itself as united was divided on the issue of ordination of women ministers, even after the conference allowing women candidature for ministry in 1974. Following the decision, the credentials of female clergy were questioned and there was fierce opposition from male ministers and even the chairman of the district, who even told her on the eve of the oral examination at the synod that he had no intention of passing her. ${ }^{10}$

Bishop Mike Voster of MCSA, Natal Coast district adds that the humiliation suffered by the late Reverend Oosthuizen did not end there. Even after ordination in October 1976, the opposition persisted. It even took on ecumenical form, in that ministers and members of other denominations refused to greet her. Some told her that if she came to share in a service in their church, she should not wear her clerical attire.

10 Methodist Church of Southern Africa (MCSA). Rev. Constance Oosthuizen: A Brief Tribute: Extract From Synod Address by Bishop Mike Voster, Natal Coastal District. http://www. methodist.org.za/news/07102016-1401 (accessed 29 October 2016). 
Contrary to such humiliation and marginalisation of female clergy, the first black woman to be ordained as deaconess in 1985, was Sister Mavis Mbilini. Sister Mbilini became the first black woman to be ordained for ministry of Word and Sacrament, was Sister Mavis Mbilini. Reverend Purity Malinga became the first black woman to date to assume the position of bishop from 1999 to 2008, as the Bishop of the Natal Coast District. The above reflects that even after 40 years, female clergy continue to be side-lined in the MCSA.

The above-mentioned women are just a few of the many women in ministry who have contributed and are still contributing positively and effectively to the welfare of the church. St. Therese of Lisieux, who died in 1897, was canonised in 1925 by Pope John Paul II as a Doctor of the Church. Her writings clarified her spiritual and selfless love, which is a rare talent of men. Mother Teresa served the poor, the leper, the sick, the orphaned as well as the HIV/AIDS sufferer and those affected for over 45 years in several countries. Her work contributed towards church ministry and thus garnered the following awards: the Indian Padmashri Award in 1962 and the prestigious Nobel Peace Prize in 1979 (Green 2004, 123).

Aside from Mother Teresa and St. Therese of Lisieux, other women contributed enormously to the ministry of the MCSA and also other denominations, as described by Riss (2013) who cites the example of Hildegard of Bingen (1098-1179) in his article, Women Throughout History as Leaders: A Brief History of Some Women in Ministry.

Hildegard of Bingen was a German abbess and a writer known throughout all of Europe. She was skilled in subjects as diverse as technology, medicine and politics and did not hesitate to rebuke the sins of the greatest men of her time in both the church and the state. She exerted an immense influence among many people, including the Emperor Frederick Barbarossa and various kings, prelates and saints. A number of miracles were attributed to her during her lifetime.

From the above examples it is evident that women have played an essential role in ministry and have contributed positively towards God's glorification and community development. This gives rise to the questions: Is this kind of potential not abundant in the MCSA; or is the MCSA disregarding it and failing to recognise women as made in the image of God?

The contributions that women have made in the ministry and their tireless work for the ministry have already been illustrated. It has also been shown how these women have made inroads where their men counterparts have failed or dared to go.

\section{MISSIONAL PARADIGM}

One thing needs to be clear, before proceeding any further. The value of men and that of women is perfectly equal in the eyes of God. "There is neither Jew nor Greek, there is neither bond nor free, there is neither male nor female: for ye are all one in 
Christ Jesus" (Galatians 3:28, my emphasis). The spiritual standing of every human being, regardless of nationality, class or gender is the same. The ground at the foot of the cross is level - women matter as much as men. This is abundantly clear from the life and ministry of Jesus and the apostles (Batchelor 2008). The above was endorsed by the MCSA at its Charter Mission Congress, held in Mthatha in December 2004. In the Charter the MCSA resolved to take intentional and sustained action to implement the four mission imperatives ${ }^{11}$ in the following areas:

The healing ministry; deepening our understanding of African and other spiritualties; coordinated programmes of Christian education; information and communication; building meaningful relationships that transcend racism, sexism and all other forms of discrimination; a vigorous response to HIV and AIDS; informing our prophetic ministry by research into socio-economic issues; identifying land for sustainable livelihood; sacrificial giving; becoming a church in solidarity with the poor; providing training in evangelism; training ministers for the African context; implementing anti-basis training; becoming a more youth and children centred church.

It has now been 12 years since the Charter was adopted by the MCSA, but racism, sexism and all other forms of discrimination remain apparent, especially on women clergy. As Reverend Charmaine Morgan and the Bishop Mike Voster indicate, there has been no change. The MCSA is still standing at four per cent female superintendents and no female bishops. This clearly reflects the marginalisation of women and that patriarchy is rife in the MCSA. There is an urgent need for the MCSA to address these imbalances, as it faces 40 years of women in ministry. Morgan asks the questions: What lies behind (Southern) African people's challenge to female leadership; and why is the MCSA showing lacklustre response to empowering women for leadership positions?

Reading Voster and Morgan's statements, leads to the conclusion that the female clergy has been greatly harmed by marginalisation. The MCSA has deviated from the Rule of Life that clearly stipulates guarding against "doing harm, avoiding evil of every kind, especially that which is more generally practised". ${ }^{12}$ The evil that the MCSA is practising, doing harm to the female clergy, is marginalisation and segregation based on gender. This practice has caused great damage to the dignity of clergywomen and has undermined the church of Christ. Surely Christ cannot have this in the church, as earlier illustrated in the way Christ treated women in New Testament times.

The fact is that the pendulum regarding the role of women in the church has swung too far in both directions and yet where humans have failed, God promises

11 Methodist Church of Southern Africa (MCSA). Four imperatives are: spirituality, evangelism and church growth, justice and service, development and economic empowerment. www.methodist. org.za/units/mission (accessed 29 October 2016). (Added hereto is education.)

12 Methodist Church of Southern Africa (MCSA). The Methodist ethos. www.methodist.org.za/ publications/laws/chapter3 (accessed 29 October 2016). 
victory, peace and restoration. This is why both sides in this debate need to seek wisdom and guidance from God's Word in order to grow in the unity of the faith. Upon considering women's roles in the church, remember also the broader idea of ministry itself. There are role distinctions within the church that are not in dispute (cf. 1 Corinthians 12). You don't ever hear the argument that a man gifted in teaching is more valuable than a man gifted in encouragement. The nature of a body is that different members perform different functions, yet each member is equal in importance. Different does not mean better or lesser.

Firstly, it is important that the MCSA takes cognisance and recognises that all people are called to the priesthood of believers. It cannot purely be a theoretical belief, but must be practical and be acknowledged by the church, laity, presbyters and male ministers. In addressing this, the MCSA should call and confess that they have sinned before God and His people by disregarding women. The acknowledgement of sin brings forgiveness. The women in the MCSA ministry and others will definitely find it in their hearts to forgive and forget the injustice of the past.

Secondly, the MCSA should put in place clear and straightforward dogma that governs the church, especially in terms of women ministry. It must be clear that segregation and marginalising women are sins and must be treated as such.

Thirdly, the MCSA should devise means of inculcating a spirit of koinonia ${ }^{13}$ among the clergy that will assist it to eradicate patriarchy and gender disparities, through the training of the male minister to respect their female counterparts by changing their attitude and seeing women as partners in God's vine, not competitors. The empowerment of women for leadership positions should be given priority, so that the MCSA may contribute towards the realisation of their God-given talents, potential and wisdom. It will make women feel part of the church and not people who are only good for special services like healing, praying for the sick and pastoral aftercare. Women must be part of the leadership of the church. This is achievable if women are well equipped, trained and empowered. Women will bring forth a feminine element, rare in men. This feature is the one that brings warmth and comfort to the broken and reassures them that God loves them despite the circumstances.

Fourthly, the MCSA should move away from the mentality of women as gatekeepers of their homes. The church leadership, which is comprised of men, should draw in women with potential and place them in strategic positions in the MCSA. There must be an inclusive leadership. There must be "togetherness" in discernment.

Fifthly, the missio Dei is possible if God is given the opportunity to work in the hearts and minds of his people. The MCSA should allow God to work and for God

13 Christian fellowship or communion with God or with fellow Christians; said in particular of the early Christian community of faith. sbvt.org/ministry-teams/ministry-teams-koinonia/ (accessed 29 October 2016). 
to be the treasurer and custodian of the church, not men. The Holy Spirit must guide the MCSA and sustain the church of God.

Lastly, the MCSA should adopt a pastoral approach towards their congregation and community, thereby drawing out the latent capacity of women being considerate as mothers. This ministry as a pastoral function is ecclesiological and embedded in the missio Dei, hence the term paraklesis. Paraklesis is God-based and is from God alone. Thus it is the function mandated to humanity to look after God's creation, which encompasses all. This function is not gender-based and is mandatory to all human beings, irrespective of their gender and to be exercised by the church authorities and those in ministry. The church, as the tool for this mission, should be in a position to implement and complement this mission.

\section{CONCLUSION}

As the discussion draws to a close, the author would like to point out that there are no special traits that can be ascribed to clergywomen for them to qualify to be called. God calls everybody, irrespective of gender in their particular circumstances to follow Christ. Calling does not require a special skill, but asks for obedience and humility to the call of God. Calling is not justified by a particular talent, because only God knows the reason He calls on that specific person. The MCSA must acknowledge Jesus as the Head of the church. It must accept that it has sinned before God and women in all its dealings pertaining to the ordination of female clergy - and it should seek forgiveness from God and the female clergy. The church, as agent of change, has been sent by God for the missio Dei. It should ensure that all the stringent laws that bring about the marginalisation of clergywomen are removed, and that the relationship between clergymen and women is that of the brotherhood of all believers.

\section{REFERENCES}

Batchelor, D. 2008. God's role for Women in Ministry: Amazing Facts. Inc.www.amazingfacts. org/media-library/book/e/2/t/gods-role-for-women-in-ministry (accessed 25 August 2016).

Bosch, D. J. 2007 (revised). Transforming Mission: Paradigm Shifts in Theology Mission. Maryknoll: Orbis Books.

Chifungo, P. 2015. Women and the Church: A Case Study of the CCAP, Nkhoma Synod, Malawi. In "Living with Dignity: African Perspectives on Gender Equality." Sun Press: 147-158, edited by E. Mouton, G. Kapuma, L. Hansen and T. Togom.

Chitando, E. 2012. Religion and Masculinities in Africa: The Impact of HIV Infection and GenderBased Violence. In "Men in the Pulpit, Women in the Pew? Addressing Gender Inequality in Africa." Sun Press: 71-82, edited by J. Hendricks, E. Mouton, L. Hansen and E. le Roux. 
Ericson, N. R. 1987. "The NT Use of the OT: A Kerygmatic Approach.” Journal of the Evangelical Theological Society, 30 (3): 337-342.

Greene, M. 2004. Mother Teresa: A Bibliography. London: Greenwood Press.

Hansrod, M. 2016. "Women Ministers Celebrated in Cape of Good Hope District." New Dimension Vol.12.

Hoekema, A. A. 1994. Created in God's Image. Grand Rapids, Michigan: Eerdmans Publishing.

Horell, J. S. 2009. "In the Name of the Father, Son and Holy Spirit: Toward a Trinitarian Worldview." Bibliotheca Sacra, Vol. 66, 131-146.

Loader, J. A. 1987. Image and Order: Old Testament Perspectives on the Ecological Crisis - are we killing God's Earth; Ecology and Theology? Pretoria: University of South Africa.

Marumo, P. O. 2016. Christianity and African Traditional Religion in Dialogue: An Ecological Future for Africa. PhD thesis, North-West University.

MCSA Minutes of Conference 2015.

Millard, J. A. 1999. Let the Word Spread. Pretoria: UNISA Press.

Miller, B. 2013. What the Bible says about Women in Ministry. Christ Unlimited Ministries. bibleresources.org/women-in-ministry/ (accessed 23 August 2016).

Mkhwanazi, F. S. 2014. Women Ministries in Mission with Reference to the Methodist Church of Southern Africa. PhD thesis, University of Pretoria

Mkhwanazi, F. S. and Kgatla, S. T. 2015. The place of women in the mission of the Methodist Church of Southern Africa. Studia Historiae Ecclesiasticae 41 (2): 180-198.

Mtshiselwa, N. 2015. "Reconstructing a Deuteronomistic Athaliah in the (South) African Context: A Critique of the Patriarchal Perception of Women." Verbum et Ecclesia 36 (1): 1-8.

Mtshiselwa, V. N. N. and Masenya (ngwan'a Mphahlele), M. 2016. "South African Female Presidential Leadership and the Inevitability of a Donga as Final Destination? Reading the Deuteronomistic Athaliah the Bosadi Way." Verbum et Ecclesia 37 (2): 1-8.

Oduyoye, M. A. 2001. Introducing African Women Theology. Sheffield Academic Press.

Oosthuizen, C. M. 1990. Conquerors through Christ: The Methodist Deacons in South Africa. Reynolds: Port Shepstone.

Riss, R. M. 2013. Women Throughout History as Leaders: A Brief History of some Women in Ministry. Christ Unlimited Ministries. Bibleresources.org/women-in-ministry (accessed 23 August 2016).

Ruether, R.R. 1993. Creation: Rosemary Radford Ruether and Feminist Theology; What does it mean to be human in God's image? San Francisco. Fortress Press.

Rutoro, E. 2012. An Analysis of the Impact of Socio-Cultural Factors on the Effectiveness of Gender Sensitive Policies in Educational Management: A Case Study of Masvingo Province. $\mathrm{PhD}$ thesis, Zimbabwe Open University.

Strivers, R. L. 2004. "Presbyterian Energy Policy: The Present Context." Church and Society: 78-86, March/April.

Wijngaards, J. 2011. The pope's “teaching” on why women can't be priests - a new focus? Based on a talk to Cleopas Society, London. www.womenpriests.org/teaching/newfocus (accessed 30 August 2016). 